\title{
Desulfovibrio marinus sp. nov., a moderately halophilic sulfate-reducing bacterium isolated from marine sediments in Tunisia
}

\author{
O. Ben Dhia Thabet, ${ }^{1,2}$ M.-L. Fardeau, ${ }^{1}$ C. Suarez-Nuñez, ${ }^{1,3}$ M. Hamdi, ${ }^{2}$ \\ P. Thomas, ${ }^{1}$ B. Ollivier ${ }^{1}$ and D. Alazard ${ }^{1,3}$
}

Correspondence

D. Alazard

didier.alazard@univmed.fr

\footnotetext{
${ }^{1}$ Laboratoire de Microbiologie IRD, UMR 180, Universités de Provence et de la Méditerranée, ESIL, Case 925, 163 Avenue de Luminy, 13288 Marseille cedex 9, France

${ }^{2}$ Laboratoire d'Ecologie et de Technologie Microbienne, INSAT, 1080 Tunis, Tunisia

${ }^{3}$ Instituto Mexicano del Petróleo, Programa de Biotecnología del Petróleo, 07730 México DF, Mexico
}

Two novel sulfate-reducing bacterial strains, designated $\mathrm{E}-2^{\top}$ and IMP-2, were isolated from geographically distinct locations. Strain $\mathrm{E}-2^{\top}$ was recovered from marine sediments near Sfax (Tunisia), whereas strain IMP-2 originated from oilfield production fluids in the Gulf of Mexico. Cells were Gram-negative, non-sporulated, motile, vibrio-shaped or sigmoid. They were strictly anaerobic, mesophilic and moderately halophilic. Sulfate, sulfite, thiosulfate and elemental sulfur served as electron acceptors, but not nitrate or nitrite. $\mathrm{H}_{2}$ (with acetate as carbon source), formate, fumarate, lactate, malate, pyruvate, succinate and fructose were used as electron donors in the presence of sulfate as terminal electron acceptor. Lactate was oxidized incompletely to acetate. Fumarate and pyruvate were fermented. Desulfoviridin and c-type cytochromes were present. 16S rRNA gene sequence analysis of the two strains showed that they were phylogenetically similar ( $99.0 \%$ similarity) and belonged to the genus Desulfovibrio, with Desulfovibrio indonesiensis and Desulfovibrio gabonensis as their closest phylogenetic relatives. The $\mathrm{G}+\mathrm{C}$ content of the DNA was respectively 60.4 and $62.7 \mathrm{~mol} \%$ for strains $\mathrm{E}-2^{\top}$ and IMP-2. DNA-DNA hybridization experiments revealed that the novel strains had a high genomic relatedness, suggesting that they belong to the same species. We therefore propose that the two isolates be affiliated to a novel species of the genus Desulfovibrio, Desulfovibrio marinus sp. nov. The type strain is strain E-2 ${ }^{\top}\left(=\mathrm{DSM} 18311^{\top}=\mathrm{JCM} 14040^{\top}\right)$.
Sulfate-reducing bacteria (SRB) are widely present in natural habitats with high sulfate concentrations such as marine environments, where they contribute significantly to organic matter mineralization (Fauque \& Ollivier, 2004). They are defined by their ability to use sulfate as a terminal electron acceptor during anaerobic respiration. Phylogenetically, they may be divided into four major groups, based on 16S rRNA gene sequence analysis. They include the Gram-negative SRB of the Deltaproteobacteria, the Gram-positive spore-forming SRB, the deeply branching thermophilic SRB and the thermophilic archaeal sulfate reducers (Castro et al., 2000; Fauque \& Ollivier, 2004; Stackebrandt et al., 1995). The mesophilic members of the Deltaproteobacteria represent the largest group of SRB, now including around 40 genera. Members of the genus

Abbreviation: SRB, sulfate-reducing bacteria.

The GenBank/EMBL/DDBJ accession numbers for the 16S rRNA gene sequences of strains E-2 ${ }^{\top}$ and IMP-2 are respectively DO365924 and D0365925.
Desulfovibrio have been isolated frequently from marine environments, including Desulfovibrio acrylicus (van der Maarel et al., 1996), D. africanus (Campbell et al., 1966), D. giganteus (Esnault et al., 1988), D. gigas (Le Gall, 1963) and D. inopinatus (Reichenbecher \& Schink, 1997). Halotolerant to halophilic Desulfovibrio species have also been recovered from oilfield environments (Birkeland, 2005); these include Desulfovibrio vietnamensis (Dang et al., 1996) and D. longus (Magot et al., 1992), considered as halotolerant, and Desulfovibrio gabonensis (TardyJacquenod et al., 1996), D. capillatus (Miranda-Tello et al., 2003), D. bastinii (Magot et al., 2004), D. indonesiensis (Feio et al., 1998) and D. gracilis, considered as moderate halophiles. Although most of these latter species were isolated from oilfield production waters, it is difficult to reach conclusions about the indigenous character of these bacteria with regard to oil reservoirs: are they contaminants or common inhabitants of deep oil reservoirs? This question remains unanswered because of possible contamination through drilling or water-flooding processes 
(Magot, 2005). In this study, we report on the isolation of two moderately halophilic strains of SRB that were recovered from marine sediments contaminated by industrial activities and from an oil-water separation system treating oilfield production fluids. Their phenotypic, genotypic and phylogenetic characteristics suggest that they represent a novel species of the genus Desulfovibrio.

Strain $\mathrm{E}-2^{\mathrm{T}}$ was isolated from marine sediments contaminated by industrial activities (phosphogypsum disposal resulting from phosphoric acid production) near Sfax (Tunisia), while strain IMP-2 was isolated from an oilwater separation tank treating production fluids from an offshore production platform in the Gulf of Mexico. Samples were collected in sterile glass bottles and kept at room temperature until used. Standard anaerobic techniques were used throughout this study (Balch et al., 1979; Hungate, 1969). Enrichment and isolation were performed using basal SRB growth medium, containing (per litre distilled water) $1 \mathrm{~g} \mathrm{NH}_{4} \mathrm{Cl}, 0.3 \mathrm{~g} \mathrm{~K}_{2} \mathrm{HPO}_{4}, 0.3 \mathrm{~g} \mathrm{KH}_{2} \mathrm{PO}_{4}$, $0.1 \mathrm{~g} \mathrm{KCl}, 0.1 \mathrm{~g} \mathrm{CaCl}_{2}, 0.2 \mathrm{~g} \mathrm{MgSO}_{4} .7 \mathrm{H}_{2} \mathrm{O}, 30 \mathrm{~g} \mathrm{NaCl}$, $0.2 \mathrm{~g}$ yeast extract, $0.5 \mathrm{~g}$ cysteine hydrochloride, $1 \mathrm{mg}$ resazurin and $10 \mathrm{ml}$ trace mineral element solution (Balch et al., 1979). The $\mathrm{pH}$ was adjusted to 7 with $10 \mathrm{M} \mathrm{KOH}$ and the medium was boiled under a stream of $\mathrm{O}_{2}$-free $\mathrm{N}_{2}$ gas and cooled to room temperature. Aliquots were dispensed into Hungate tubes $(5 \mathrm{ml})$ and serum bottles
(20 ml) under a stream of $\mathrm{N}_{2} / \mathrm{CO}_{2}(80: 20, \mathrm{v} / \mathrm{v})$ gas and the sealed vessels were autoclaved for $45 \mathrm{~min}$ at $110{ }^{\circ} \mathrm{C}$. Prior to inoculation, $\mathrm{Na}_{2} \mathrm{~S} .9 \mathrm{H}_{2} \mathrm{O}$ and $\mathrm{NaHCO}_{3}$ were injected from anaerobic sterile stock solutions to respective final concentrations of 0.04 and $0.2 \%(\mathrm{w} / \mathrm{v})$. Liquid cultures were incubated at $35{ }^{\circ} \mathrm{C}$ for 1 week. Pure cultures were obtained by repeated application of the agar roll-tube dilution method (Hungate, 1969). Purity of the isolates was checked by microscope observation and inoculation in sulfate-free media containing yeast extract and sugars. $D$. gabonensis DSM $10636^{\mathrm{T}}$ and D. indonesiensis DSM $15121^{\mathrm{T}}$ were obtained from the Deutsche Sammlung von Mikroorganismen und Zellkulturen (DSMZ; Braunschweig, Germany) and cultivated according to the procedures recommended by the DSMZ. In order to characterize the two isolates phenotypically, standard and specific tests for SRB were performed, including Gram reaction, cell morphology, motility and determination of the electron donors and acceptors used and the presence of desulfoviridin and c-type cytochromes (Postgate, 1984), as well as other tests as shown in Table 1 or included in the species description. Substrates were tested at a final concentration of $20 \mathrm{mM}$ in SRB medium. To test for electron acceptors, sodium thiosulfate, sodium sulfate, sodium sulfite, elemental sulfur and nitrate were added to the medium at final concentrations of $20 \mathrm{mM}, 20 \mathrm{mM}, 2 \mathrm{mM}, 2 \%$ (w/v) and $10 \mathrm{mM}$, respectively.

Table 1. Differentiating physiological and biochemical characteristics of strains $\mathrm{E}-2^{\top}$ and IMP-2, $D$. gabonensis DSM $10636^{\top}$ and D. indonesiensis DSM $15121^{\top}$

Data for D. gabonensis DSM $10636^{\mathrm{T}}$ and D. indonesiensis DSM $15121^{\mathrm{T}}$ were taken from Tardy-Jacquenod et al. (1996) and from Feio et al. (1998), respectively, unless indicated. Data for strains E-2 ${ }^{\mathrm{T}}$ and IMP-2 were taken from this study. ND, Not determined.

\begin{tabular}{|c|c|c|c|c|}
\hline Characteristic & Strain $\mathrm{E}-2^{\mathrm{T}}$ & Strain IMP-2 & $\begin{array}{l}\text { D. gabonensis } \\
\text { DSM } 10636^{T}\end{array}$ & $\begin{array}{l}\text { D. indonesiensis } \\
{\text { DSM } 15121^{\mathrm{T}}}\end{array}$ \\
\hline \multicolumn{5}{|l|}{ Temperature for growth $\left({ }^{\circ} \mathrm{C}\right)$} \\
\hline Range & $20-50$ & $25-40$ & $15-40$ & $10-37$ \\
\hline Optimum & 37 & 35 & 30 & $\mathrm{ND}$ \\
\hline \multicolumn{5}{|l|}{$\mathrm{pH}$ for growth } \\
\hline Range & $6.5-8.5$ & $6.5-8.2$ & $6.4-8.2$ & $6.5-8.5$ \\
\hline Optimum & 7.0 & 7.0 & $6.9-7.3$ & $6.8-7.2$ \\
\hline \multicolumn{5}{|c|}{$\mathrm{NaCl}$ concentration for growth (\%) } \\
\hline Range & $0.5-11$ & $0.5-10$ & $1-17$ & $1-10^{*}$ \\
\hline Optimum & 5 & 2 & $5-6$ & $5-6^{*}$ \\
\hline \multicolumn{5}{|l|}{ Electron donors } \\
\hline Malate & + & + & + & $-{ }^{\star}$ \\
\hline Butanol & - & - & + & $+1-$ \\
\hline Ethanol & + & + & + & - \\
\hline Fructose & + & + & $+^{\star}$ & $-{ }^{\star}$ \\
\hline Fumarate fermentation & + & + & + & $-{ }^{\star}$ \\
\hline \multicolumn{5}{|l|}{ Electron acceptors } \\
\hline Elemental sulfur & + & + & + & $-{ }^{\star}$ \\
\hline Fumarate & - & - & + & $-{ }^{\star}$ \\
\hline DNA G $+\mathrm{C}$ content $(\mathrm{mol} \%)$ & 60.4 & 62.7 & 59.5 & $58.1^{\star}$ \\
\hline
\end{tabular}

${ }^{\star}$ Data from this study. 
Black, circular colonies, $2.5 \mathrm{~mm}$ in diameter, appeared after 1 week of incubation at $37^{\circ} \mathrm{C}$ in roll tubes. Cells of strains $\mathrm{E}-2^{\mathrm{T}}$ and IMP-2 were vibrioid and motile. The cells were approximately $0.5 \mu \mathrm{m}$ in diameter and $1.5-2.5 \mu \mathrm{m}$ long and occurred singly and in chains. Electron microscope observations revealed that both isolates were motile by a polar flagellum. Gram staining was negative and spores were never observed. Strains E-2 ${ }^{\mathrm{T}}$ and IMP-2 were strictly anaerobic micro-organisms, slightly to moderately halophilic, growing optimally in media containing 5 and $2.5 \%$ $(w / v)$ salts, respectively. No growth was observed in the absence of $\mathrm{NaCl}$. The optimum $\mathrm{pH}$ for both isolates was 7.0. The two isolates grew optimally at $37{ }^{\circ} \mathrm{C}$ but they had a slightly different temperature ranges for growth: strain $\mathrm{E}-2^{\mathrm{T}}$ grew at $20-50{ }^{\circ} \mathrm{C}$ whereas strain IMP-2 grew at $25-40{ }^{\circ} \mathrm{C}$. In the presence of sulfate, both isolates oxidized the following substrates: $\mathrm{H}_{2}$ (with acetate as carbon source), formate, fumarate, lactate, malate, pyruvate, succinate, ethanol and fructose. Acetate was produced from lactate oxidation. No growth was observed on acetate, benzoate, butyrate, citrate, propionate, valerate, butanol, glycerol, 2-propanol, methanol, glucose, Casamino acids or peptone. Pyruvate was fermented into acetate, $\mathrm{H}_{2}$ and $\mathrm{CO}_{2}$, whereas fumarate was disproportionated into acetate and succinate. The isolates used elemental sulfur, sulfate, sulfite and thiosulfate but not fumarate, nitrate or nitrite as electron acceptors. Desulfoviridin was present as bisulfite reductase. Two peaks, at 418 and $550 \mathrm{~nm}$, were detected in cell-free extracts reduced with dithionite, characteristic of $c$-type cytochromes.

The $\mathrm{G}+\mathrm{C}$ content of the DNA was determined by HPLC at the Identification Service of the DSMZ as $60.4 \mathrm{~mol} \%$ for strain $\mathrm{E}-2^{\mathrm{T}}$ and $62.7 \mathrm{~mol} \%$ for strain IMP-2. The $16 \mathrm{~S}$ rRNA genes of strains E- $2^{\mathrm{T}}$ and IMP-2 were amplified and sequenced as described elsewhere (Maidak et al., 2001; Miranda-Tello et al., 2003; Weisburg et al., 1991). Sequences of 1524 and 1478 nucleotides, respectively, of the $16 \mathrm{~S}$ rRNA genes of strains $\mathrm{E}-2^{\mathrm{T}}$ and IMP-2 were determined and aligned manually using the alignment editor BioEdit version 5.0.9 (Hall, 1999). The 16S rRNA gene sequences of the new isolates shared $99.0 \%$ similarity, suggesting that they are closely related phylogenetically. The strains belonged to the genus Desulfovibrio, of the class Deltaproteobacteria, with D. indonesiensis Ind $1^{\mathrm{T}}(98.3 \%$ similarity) and D. gabonensis SEBR $2840^{\mathrm{T}}(97.1 \%$ similarity) as their closest phylogenetic relatives (Fig. 1).

DNA-DNA hybridization experiments were carried out at the DSMZ. DNA was isolated by chromatography on hydroxyapatite by the procedure of Cashion et al. (1977) and DNA-DNA hybridization was performed as described by De Ley et al. (1970) with the modification described by Huß et al. (1983) and Escara \& Hutton (1980), using a Gilford System model 2600 spectrometer equipped with a Gilford model 2527-R thermoprogrammer and plotter. Renaturation rates were computed with the TRANSFER.BAS program of Jahnke (1992). A quite high DNA-DNA reassociation value of $64.5 \pm 3.8 \%$ (mean of four values) was obtained between strain E-2 ${ }^{\mathrm{T}}$ and IMP-2. This value is

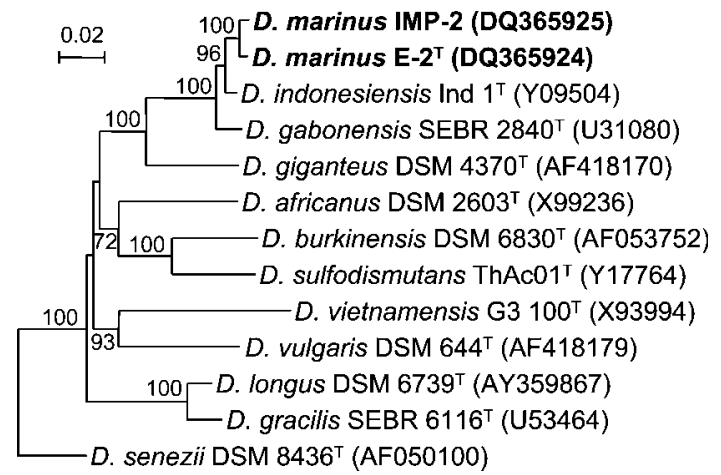

Fig. 1. Phylogenetic tree based on a comparison of the $16 \mathrm{~S}$ rRNA gene sequences of strains $E-2^{\top}$ and IMP-2 and selected members of the genus Desulfovibrio. Desulfovibrio senezii DSM $8436^{\top}$ was taken as an outgroup. Bootstrap values (from 100 replications) are shown at branching points; only values above 80 are shown. Bar, 0.02 substitutions per nucleotide position.

close to the threshold value of $70 \%$ for assignment of strains to the same species (Wayne et al., 1987). Moreover, the few physiological differences that exist between the two isolated strains are not sufficient to differentiate them at the species level (Table 1). Strains E-2 ${ }^{\mathrm{T}}$ and IMP-2 should therefore be assigned to the same species of the genus Desulfovibrio. DNA-DNA hybridization data revealed relatedness of only $15.7 \%$ between strain $\mathrm{E}-2^{\mathrm{T}}$ and $D$. indonesiensis DSM $15121^{\mathrm{T}}$ and $26.0 \%$ between strain $\mathrm{E}-2^{\mathrm{T}}$ and D. gabonensis DSM $10636^{\mathrm{T}}$. Strain IMP-2 showed $12.4 \%$ relatedness to D. indonesiensis DSM $15121^{\mathrm{T}}$ and $35.2 \%$ relatedness to D. gabonensis DSM $10636^{\mathrm{T}}$. Among the phenotypic differences that exist between $D$. indonesiensis and the two isolates, the former did not use ethanol, malate or fructose as electron donors or elemental sulfur as a terminal electron acceptor and did not ferment fumarate. In contrast to our isolates, $D$. gabonensis oxidized butanol and used fumarate as an electron acceptor (Table 1). Based on the phenotypic, genotypic and phylogenetic characteristics of our isolates, we propose to assign them to a novel species, Desulfovibrio marinus sp. nov. Finally, our results indicated that phylogenetically similar SRB inhabit both marine and oilfield environments. In this respect, marine SRB may be possible contaminants of oil reservoirs through water-flooding processes in particular, thus contributing to oil souring and corrosion problems in the oil industry (Crolet, 2005; Vance \& Thrasher, 2005).

\section{Description of Desulfovibrio marinus sp. nov.}

Desulfovibrio marinus (ma.ri'nus. L. masc. adj. marinus of or belonging to the sea, marine).

Cells are strictly anaerobic, vibrio-shaped or sigmoid, $0.5 \times 1.5-2.5 \mu \mathrm{m}$, occurring singly and in chains. Motile by a polar flagellum. Grows at $20-50{ }^{\circ} \mathrm{C}$, with optimum growth at $37{ }^{\circ} \mathrm{C}$. Grows in the presence of $\mathrm{NaCl}$ at 0.5 to $11 \%$, with optimum growth around $2.5-5 \%$. The optimum $\mathrm{pH}$ for 
growth is 7.0; growth occurs at $\mathrm{pH} 6.5-8.5$. Uses $\mathrm{H}_{2}$, formate, fumarate, lactate, malate, pyruvate, succinate and fructose as electron donors. Lactate is converted to acetate. Substrates that are not used include acetate, benzoate, butyrate, citrate, propionate, valerate, butanol, glycerol, 2propanol, methanol, glucose, Casamino acids and peptone. Pyruvate and fumarate are fermented. Uses elemental sulfur, sulfate, thiosulfate and sulfite but not fumarate, nitrate or nitrite as electron acceptors. Desulfoviridin and $c$-type cytochromes are present. The $\mathrm{G}+\mathrm{C}$ content of DNA of the type strain is $60.4 \mathrm{~mol} \%$ (HPLC).

The type strain, strain E-2 $2^{\mathrm{T}}\left(=\mathrm{DSM} 18311^{\mathrm{T}}=\mathrm{JCM}\right.$ $14040^{\mathrm{T}}$ ), was isolated from seawater near Sfax (Tunisia). A second strain of the species, IMP-2, was isolated from oilfield production fluids in the Gulf of Mexico.

\section{Acknowledgements}

Many thanks to Dr G. Fauque for improving the manuscript.

\section{References}

Balch, W. E., Fox, G. E., Magrum, L. J., Woese, C. R. \& Wolfe, R. S. (1979). Methanogens: reevaluation of a unique biological group. Microbiol Rev 43, 260-296.

Birkeland, N. K. (2005). Sulfate-reducing bacteria and archaea. In Petroleum Microbiology, pp. 35-54. Edited by B. Ollivier \& M. Magot. Washington, DC: American Society for Microbiology.

Campbell, L. L., Kasprzycki, M. A. \& Postgate, J. R. (1966). Desulfovibrio africanus sp. nov., a new dissimilatory sulfate-reducing bacterium. J Bacteriol 92, 1122-1127.

Cashion, P., Holder-Franklin, M. A., McCully, J. \& Franklin, M. (1977). A rapid method for the base ratio determination of bacterial DNA. Anal Biochem 81, 461-466.

Castro, H. F., Wiliams, N. H. \& Ogram, A. (2000). Phylogeny of sulfatereducing bacteria. FEMS Microbiol Ecol 31, 1-9.

Crolet, J.-L. (2005). Microbial corrosion in the oil industry. In Petroleum Microbiology, pp. 143-169. Edited by B. Ollivier \& M. Magot. Washington, DC: American Society for Microbiology.

Dang, P. N., Dang, T. C. H., Lai, T. H. \& Stan-Lotter, H. (1996). Desulfovibrio vietnamensis sp. nov., a halophilic sulfate-reducing bacterium from Vietnamese oil fields. Anaerobe 2, 385-392.

De Ley, J., Cattoir, H. \& Reynaerts, A. (1970). The quantitative measurement of DNA hybridization from renaturation rates. Eur $J$ Biochem 12, 133-142.

Escara, J. F. \& Hutton, J. R. (1980). Thermal stability and renaturation of DNA in dimethyl sulfoxide solutions: acceleration of the renaturation rate. Biopolymers 19, 1315-1327.

Esnault, G., Caumette, P. \& Garcia, J.-L. (1988). Characterization of Desulfovibrio giganteus sp. nov., a sulfate reducing bacterium isolated from a brackish coastal lagoon. Syst Appl Microbiol 10, 147-151.

Fauque, G. \& Ollivier, B. (2004). Anaerobes: the sulfate-reducing bacteria as an example of metabolic diversity. In Microbial Diversity and Bioprospecting, pp. 169-176. Edited by A. T. Bull. Washington, DC: American Society for Microbiology.

Feio, M. J., Beech, I. B., Carepo, M., Lopes, J. M., Cheug, C. W. S., Franco, R., Guezennec, J., Smith, J. R., Mitchell, J. I. \& other authors (1998). Isolation and characterisation of a novel sulphate-reducing bacterium of the Desulfovibrio genus. Anaerobe 4, 117-130.
Hall, T. A. (1999). BioEdit: a user-friendly biological sequence alignment editor and analysis program for Windows 95/98/NT. Nucleic Acids Symp Ser 41, 95-98.

Hungate, R. E. (1969). A roll tube method for cultivation of strict anaerobes. Methods Microbiol 3B, 117-132.

Huß, V. A. R., Festl, H. \& Schleifer, K. H. (1983). Studies on the spectrophotometric determination of DNA hybridization from renaturation rates. Syst Appl Microbiol 4, 184-192.

Jahnke, K. D. (1992). BASIC computer program for evaluation of spectroscopic DNA renaturation data from Gilford System 2600 spectrophotometer on a PC/XT/AT type personal computer. J Microbiol Methods 15, 61-73.

Le Gall, J. (1963). A new species of Desulfovibrio. J Bacteriol 86, 1120. Magot, M. (2005). Indigenous microbial community in oil fields. In Petroleum Microbiology, pp. 21-34. Edited by B. Ollivier \& M. Magot. Washington, DC: American Society for Microbiology.

Magot, M., Caumette, P., Desperrier, J. M., Matheron, R., Dauga, C., Grimont, F. \& Carreau, L. (1992). Desulfovibrio longus sp. nov., a sulfate-reducing bacterium isolated from an oil-producing well. Int $J$ Syst Bacteriol 42, 398-403.

Magot, M., Basso, O., Tardy-Jacquenod, C. \& Caumette, P. (2004). Desulfovibrio bastinii sp. nov. and Desulfovibrio gracilis sp. nov., moderately halophilic, sulfate-reducing bacteria isolated from deep subsurface oilfield water. Int J Syst Evol Microbiol 54, 1693-1697.

Maidak, B. L., Cole, J. R., Lilburn, T. G., Parker, C. T., Jr, Saxman, P. R., Farris, R. J., Garrity, G. M., Olsen, G. J., Schmidt, T. M. \& Tiedje, J. M. (2001). The RDP-II (Ribosomal Database Project). Nucleic Acids Res 29, 173-174.

Miranda-Tello, E., Fardeau, M.-L., Cayol, J.-L., Thomas, P., Ostoa, P., Ramírez, F., Fernández, L., Garcia, J.-L. \& Ollivier, B. (2003). Desulfovibrio capillatus sp. nov., a long-chained sulfate-reducing bacterium isolated from Gulf of Mexico oil well. Anaerobe 9, 97-103.

Postgate, J. R. (1984). The Sulphate-Reducing Bacteria, 2nd edn. Cambridge: Cambridge University Press.

Reichenbecher, W. \& Schink, B. (1997). Desulfovibrio inopinatus, sp. nov., a new sulfate-reducing bacterium that degrades hydroxyhydroquinone (1,2,4-trihydroxybenzene). Arch Microbiol 168, 338-344.

Stackebrandt, E., Stahl, D. A. \& Devereux, R. (1995). Taxonomic relationships. In Biotechnology Handbooks, vol. 8, Sulfate-Reducing Bacteria, pp. 49-87. Edited by L. L. Barton. New York: Plenum.

Tardy-Jacquenod, C., Magot, M., Laigret, F., Patel, B. K. C., Guezennec, J., Matheron, R. \& Caumette, P. (1996). Desulfovibrio gabonensis sp. nov., a new moderately halophilic, sulfate-reducing bacterium isolated from an oil pipeline. Int J Syst Bacteriol 46, $710-715$.

van der Maarel, M. J. E. C., van Bergeijk, S., van Werkhoven, A. F., Laverman, A. M., Meijer, W. G., Stam, W. T. \& Hansen, T. A. (1996). Cleavage of dimethylsulfoniopropionate and reduction of acrylate by Desulfovibrio acrylicus sp. nov. Arch Microbiol 166, 109-115.

Vance, I. \& Thrasher, D. R. (2005). Reservoir souring: mechanisms and prevention. In Petroleum Microbiology, pp. 123-142. Edited by B. Ollivier \& M. Magot. Washington, DC: American Society for Microbiology.

Wayne, L. G., Brenner, D. J., Colwell, R. R., Grimont, P. A. D., Kandler, O., Krichevsky, M. I., Moore, L. H., Moore, W. E. C., Murray, R. G. E. \& other authors (1987). International Committee on Systematic Bacteriology. Report of the ad hoc committee on reconciliation of approaches to bacterial systematics. Int J Syst Bacteriol 37, 463-464.

Weisburg, W. G., Barns, S. M., Pelletier, D. A. \& Lane, D. J. (1991). $16 \mathrm{~S}$ ribosomal DNA amplification for phylogenetic study. J Bacteriol 173, 697-703. 